FAN ENTREPRENEURSHIP

Fandom, Agency, and the Marketing of Hallyu in Israel

\author{
Nissim Otmazgin \\ Department of Asian Studies \\ The Hebrew University of Jerusalem \\ nissim.otmazgin@mail.huji.ac.il
}

Irina Lyan

St. Antony's College

University of Oxford

irina.lyan@sant.ox.ac.uk

\begin{abstract}
While the overall majority of Hallyu research has looked at the way fans consume Korean popular culture and how it influences their identity, this paper focuses on the way these fans serve as effective agents for marketing Hallyu and how their fandom empowers them to explore new business and social opportunities. Focusing on what we call "fan entrepreneurship," this paper examines the evolvement of fan communities in Israel and their role as cultural agents transcending different cultural and social contexts. More specifically, it analyzes their role as promoters, distributers, and entrepreneurs of Hallyu. To examine fan entrepreneurship in action, we focus on three cases of Israeli Hallyu fans who have ventured into new fields in business, education, and social activism to conceptualize the relations between fandom, agency, and the transnational marketing of Hallyu. Our findings suggest that the Hallyu experience in Israel may be relevant for understanding the grass-roots processes and mechanisms responsible for the spread and the institutionalization of cultural content across national, ethnic, and linguistic boundaries.
\end{abstract}

\title{
Keywords
}

agency; entrepreneurship; fandom; Hallyu; Korean Wave in Israel; transnational marketing 


\section{About the Authors}

Nissim Otmazgin is a Professor at the Department of Asian Studies and Director of the Institute for Asian and African Studies, The Hebrew University of Jerusalem. His recent research focuses on media industry and media policy in South Korea and Japan.

Irina Lyan is a Visiting Research Fellow at Asian Studies Centre, St. Antony's College, University of Oxford. Her research interests include international management and Korean popular culture studies. 


\section{INTRODUCTION}

Hallyu generally refers to the flow and consumption of popular culture products from South Korea to the rest of the world, which has been going on for the past two decades. In spite of pessimistic prospects and low expectations about its longevity, Hallyu fandom has been growing, starting with TV dramas, K-pop, and video games and has more recently expanded to include Korean-made cosmetics, food, and Korea-inspired fashion (E.-Y. Jung; Jin and Yoon). New Internet technologies and social media have played a central role in the spread of Hallyu. Wherever there is sufficient Internet connection, Hallyu fans tend to form online communities and sometimes meet offline as well to share their fandom and recruit more members. Concurrently, Hallyu has evolved into a lucrative business enterprise that exports various media productions to fans worldwide as well as boost the consumption of Korean-made electronic devices necessary for consuming these productions (Jin, Smartland Korea). While having its biggest presence in the Asian region, nowadays, Hallyu fans can be found in different parts of the world and across different ethnic groups-North America, Europe, Latin America, and the Middle East.

The purpose of this paper is not to deal with the images that Hallyu reflects or the fandom practices it encourages. The plethora of analysis of Hallyu rooted in media and cultural studies has already dealt with these aspects extensively (for example, E.-Y. Jung; Cho; Lie; Jung and Shim; Han; Min et al.). This paper, rather, emphasizes an overlooked aspect of Hallyu's transnational expansion that we call "fan entrepreneurship," referring to the business and social opportunities empowered by Hallyu fandom. We suggest that "fan entrepreneurship," and not the actions of companies and established promoters, has become the driving engine for the longevity of Hallyu in such faraway places as the Middle East. This paper views the fans as the main agents for spreading interest in Hallyu and constructing new markets for Korean cultural products. As the sellers and consumers, they serve as the extension of both the established industry and governmental policy. In this context, fans are far from passive recipients of cultural content, neither are they merely "cultural agents" (Jenkins), but some serve as entrepreneurs who both localize Hallyu and inspire new business and social opportunities through a variety of enterprises. Specifically, we examine how fans utilize their personal networksthe social infrastructure of any contemporary enterprise-to develop Hallyurelated business and social initiatives. Put differently, we look at how fans not only enjoy, consume, or practice Hallyu but also how they serve as effective agents for marketing Hallyu-related initiatives in places that previously knew nothing or very little about Korea.

This paper suggests that the entrepreneurial promotion of Hallyu in Israel is relevant to understand the spread of Hallyu in other parts of the world. 
Analytically, in this paper we develop a framework to understand the social and the organizational role-rather than the cultural role-that fans play in spreading contemporary culture in faraway places, such as Israel. This is because cultural products and cultural practices do not simply "appear" - they are the product of the work of agents, promoters, and entrepreneurs who make their living from this business. Secondly, we suggest that the notion of "entrepreneurship" is important for understanding the global spread as well as the longevity of Hallyu. Our exploratory study aims to highlight how fans do not simply consume and spread Korean popular culture but tend to initiate Korean-oriented contacts. Many view their future life and employment entrenched in Korean culture. Surprisingly, while a few works have documented the expression of fan activism through the translation of TV dramas and songs, the organization of meetings, or the support of Hallyu stars (for example, S. Jung; Lee), this was not analyzed within the framework of entrepreneurship and, as far as we know, no systematic academic attention has been paid to the entrepreneurial aspect of Hallyu.

In what follows, we discuss the notion of entrepreneurship in popular culture, emphasizing its unique context in the media industries and the way it is shaping the organizational pathways that fans create as an extension to their fandom. Building on previous studies of Israeli and Palestinian fans of Hallyu (Otmazgin and Lyan; Lyan and Levkowitz, "Hallyu Land"), we first examine the nature of Hallyu fandom in the Middle East and, more specifically, focus on the institutionalization of fan communities in Israel over the past decade, emphasizing the role of fans in this process. Next, based on semi-structured interviews with Hallyu fans and both online and offline observations of fan communities in Israel during the last decade, we focus on three illustrative cases of female Hallyu entrepreneurs: a businesswoman who established a small food enterprise following her love of Korean drama; a student who chose to take Korean Studies following her interest in K-pop, and eventually became a Korean language translator; and an NGO activist who enthusiastically promotes knowledge about Korean culture, history, and society. What brings these three stories together is that they encapsulate the way Hallyu is spreading through and beyond social networks, the way it influences the life of consumers, and the way it inspires them to become entrepreneurs. Finally, we discuss the intended and the unintended consequences of fan entrepreneurship as a driving force behind Hallyu's global expansion.

\section{ENTREPRENEURSHIP AND POPULAR CULTURE}

Entrepreneurship represents a dynamic process of change brought about by the implementation of new ideas and creative solutions, and is based on the vision 
to recognize opportunities, take calculated risks, acquire necessary resources, construct new enterprises, and achieve new wealth. From an organizational point of view, entrepreneurship has the potential to overcome institutional rigidities and venture into unexplored fields. It is the process where an individual or a group of individuals forms new arrangements or perpetuates innovation within or outside organizations (Sharma and Chrisman 19). While definitions of entrepreneurship vary, Ronstadt's classic definition is a good start:

Entrepreneurship is the dynamic process of creating incremental wealth. This wealth is created by individuals who assume the major risks in terms of equity, time, and/or career commitment of providing value for some product or service. The product or service itself may or may not be new or unique but value must somehow be infused by the entrepreneur by securing and allocating the necessary skills and resources (as cited in Kuratko and Audretsch 3).

The study of entrepreneurship is most fundamentally concerned with understanding "how opportunities to bring into existence 'future' goods and services are discovered, created, and exploited, by whom, and with what consequences" (Venkataraman $120)$.

While being an established field of study in organization and management literature (for example, McGrath and MacMillian; Morris et al.), entrepreneurship researchers have largely neglected the broader social and cultural dynamics that embed enterprises (Zahra; Welter). This may explain why the concept of entrepreneurship is still overlooked in popular culture studies. Yet, entrepreneurship is central for understanding the ways in which entrepreneurs of popular cultureboth individuals and companies, within and outside the established industrymanage to utilize new marketing channels, access potential consumers, incorporate new promotional means, and create vehicles for related products and services (Peterson and Berger; Aggestam; Scott; Otmazgin, "Commodifying Asian-ness;" Otmazgin, "Anime in the US"). These entrepreneurs seek expansion opportunities through commercialized popular culture products or by using these products as a leverage for launching new businesses ideas (such as an advertising campaign using popular culture icons) and for building new enterprises.

At first glance, popular culture entrepreneurs are no different from other business-driven entrepreneurs as they all seek to make a profit by overcoming obstacles, creating new opportunities, and initiating change. Standing at the crossroads of economics, sociology, and cultural studies, cultural entrepreneurship is viewed as "the carrying out of a novel combination that results in something new and appreciated in the cultural sphere" (Swedberg 260). However, there are some important differences we should consider for our discussion of fan entrepreneurship. 
First, entrepreneurs in popular culture are confronted by a relatively high uncertainty (Hirsch). Popular culture entrepreneurs work in an especially dynamic environment where consumers tend to change their mind swiftly and where products have a very short marketing period (consider, for example, the marketing period of a K-pop music album, a Korean movie, or a television drama). Their work is affected not only by the macro-economic conditions that cause fluctuations in consumption, but also by the sometimes frantic changes in consumers' style and fashion, especially in an era of globalization (Otmazgin, "Commodifying Asianness"). Due to the creative and dynamic environment, entrepreneurs thus need to reconfigure themselves to achieve market specialty and create a close, even intimate, familiarity with the consumers. In this business, entrepreneurs have to

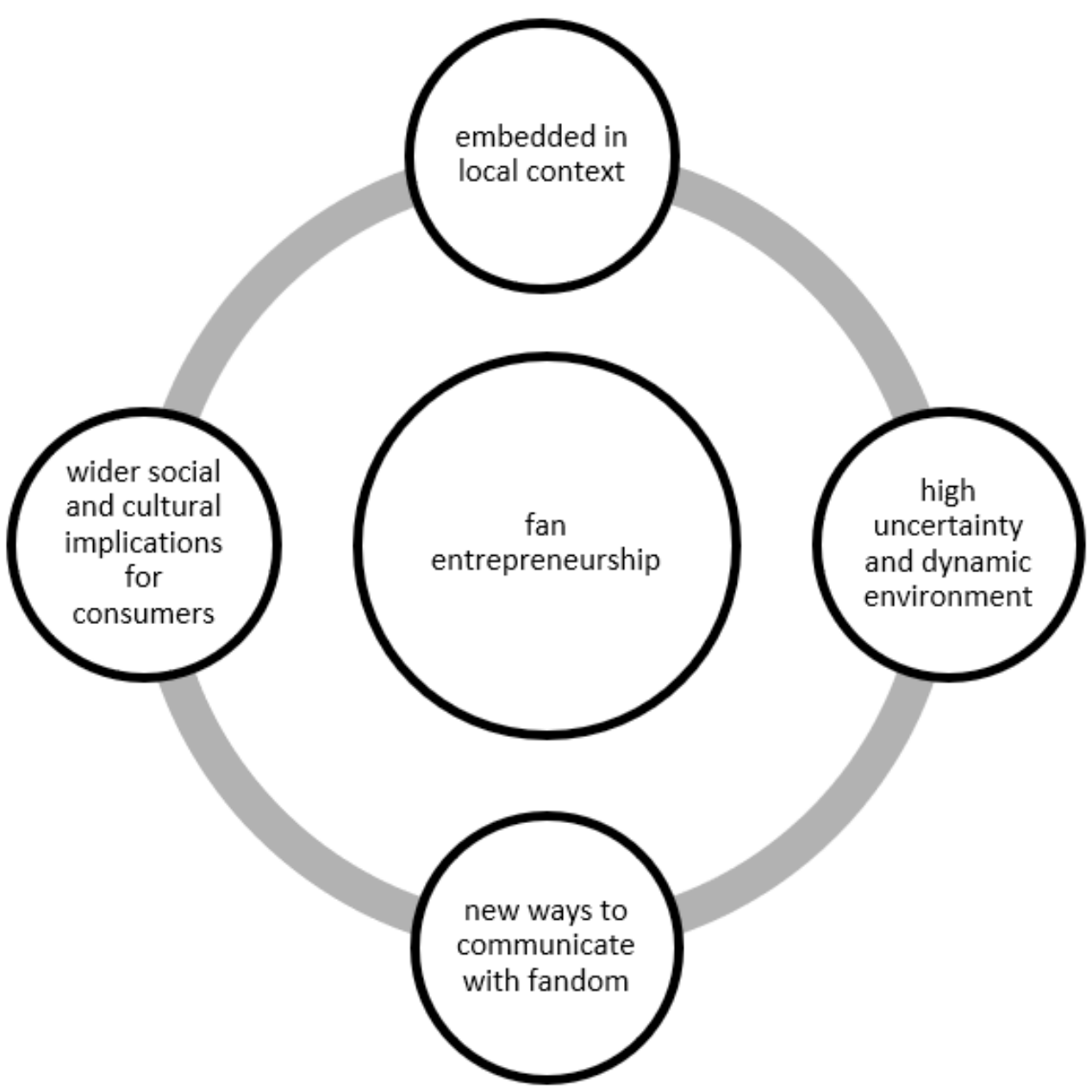

Figure 1. Characteristics of Fan Entrepreneurship 
be on constant alert for new cultural trends and preferences, find creative ways to promote their initiatives, cultivate and exploit personal connections, receive feedback from the market, and react swiftly.

Second, since they are utilizing the fascination many people have for popular culture, the work of entrepreneurs has wider social and cultural implications for consumers. As Scott points out, "cultural entrepreneurs' motivations cannot be reduced to economic interest" (242). Unlike their counterparts in other fields, popular culture entrepreneurs do not only generate value in the economic sense, but also in terms of emotions, identification, and perceptions in order to generate excitement and enthusiasm-a so-called "buzz" (Caves; Scott). This is because cultural commodities, more than other commodities, are likely to express new aspirations and provide the context for people to fulfill a wide range of social and personal attributes and purposes. In the case of Hallyu, think, for example, about the role Korean television dramas play in creating interest among viewers of other countries and introducing some aspects of Korean everyday life or history. After all, buying a pencil, a carpet, or a bathtub is different from watching a movie, reading a novel, or listening to music. The difference is in the way popular culture products promote messages and narratives, which have a wider potential to shape peoples' thoughts, identities, and even their view of space (Story 128). Popular culture entrepreneurs, thus, do not only construct mechanisms for commodifying and marketing popular culture, but also unintentionally disseminate ideas, emotions, and sensibilities together with the commodities.

Finally, unlike in other economic-driven sectors, the motives offan entrepreneurs are not purely commercial but are closely linked to their fandom. Across the world, Hallyu fans organize parties, open online shops selling goods from Korea, or set up a Korean language school not only because these activities may generate income but, more importantly, because it is important for them to build new transnational pathways that connect their home community with their fandom. As we shall see in the next sections, Israeli fans did not necessarily become engaged in Korea-related entrepreneurship to generate profit in the economic sense but, more importantly, to stay in touch with their fandom.

\section{HALLYU INSTITUTIONALIZATION IN ISRAEL AND THE WIDER MIDDLE EAST}

The spread of Hallyu in the Middle East, like in other non-Asian regions of the world, has been an overwhelmingly spontaneous process. The initial introduction of TV dramas and K-pop music to consumers was not driven by Korean media industries

or by any Korean government initiative, but rather emanated from "below" and 
spread swiftly by the fans using social media (Noh; Hemati; Otmazgin and Lyan; Lyan et al.; Oh, "Islam"). According to the Korea Foundation, the numbers of Hallyu club members more than doubled from 2014 to 2016 in Egypt (from 59,938 to 128,288 ), Jordan (from 4,825 to 10,681), and Morocco (from 4,040 to 12,050) (Oh, "Islam" 241). While Hallyu still caters to a relatively small number of dedicated fans, these fans have succeeded in generating enough interest to make other media outlets respond.

Over the past fifteen years, cable and terrestrial television stations in the Middle East have started broadcasting Korean dramas on a regular basis and the mass media began to take an increasing interest in the Hallyu phenomenon, bringing it to the attention of those who would not have known about it otherwise. The Korean Embassies in the Middle East, for their part, started to utilize Hallyu as part of their public diplomacy campaign designed to improve Korea's national image and strengthen its economic and diplomatic ties with Middle Eastern countries (Kim). For instance, the King Sejong Institute, supported by the Korean government, opened Korean language classes at local universities in Turkey, Iran, Egypt, and UAE (King Sejong Institute). To attract more tourists, the Korea Tourism Organization launched the themed travel guide "Muslim-friendly Korea" by translating its site to Arabic (as well as eleven other languages) and providing information about Halal restaurants, Muslim-friendly routes, and prayer rooms ("Muslim-friendly Travel").

What is interesting in the case of the Middle East is that Hallyu has managed to move across societies of different social, cultural, and ethnic backgrounds: both to conservative Muslim villages in Palestine, Egypt, and Iran, as well as to Orthodox Jewish women in Jerusalem, and to youngsters living in pluralistic Tel Aviv, which is considered one of the gay capitals of the world. While Hallyu has not become a mainstream phenomenon in the Middle East, it has its share of dedicated fans for whom Hallyu constitutes an important part of their identity and everyday life. Thus, the impact of Hallyu on fans should not be underestimated but rather seen as part of Hallyu's longevity beyond Asia.

While previous studies of Hallyu fandom have focused on Hallyu's popularity in the Asian countries (Cho; Chua and Iwabuchi; Lee and Nornes), the Israeli case exemplifies the ability of Hallyu to extend beyond regional and cultural boundaries and to effectively reach out to audiences of various nationalities and ethnicities. More specifically, it addresses the question of how Hallyu fans in relatively remote places negotiate their identity through cultural consumption and their active involvement with online and offline fandom (Noh; Schulze; Elfving-Hwang; Otmazgin and Lyan; Han; Min et al.). Similar to fans in other parts of the world (for example, Noh; Oh, "Lovers"), the overall majority of Hallyu fans in Israel are young women in their late teens and early twenties. This age group's mastery of Internet tools could explain 
its greater participation in online consumption and management of online fandom communities, making Hallyu a strongly fan-driven phenomenon based on the increased use of social media in the so-called "Hallyu 2.0" era (E.-Y. Jung; Oh and Park; Lee and Nornes; Jin, New Korean Wave). The overall majority of fans have also never been to Korea. This is understandable due to the geographical distance and high cost of traveling there as well as the food restrictions for fans who keep Jewish kosher laws (for example, no pork, seafood or mixing dairy and meat). These fans experience Korean culture mostly through Korean TV dramas and K-pop to the extent that fandom itself becomes an imaginary journey. At the same time, Hallyu is domesticated by local fan communities and serves as a means to connect one's own identity with an imaginary "Hallyu Land" (Lyan and Levkowitz, "Hallyu Land"). That is, Hallyu becomes the gateway to a broader interest in Korea that includes the growing appeal in Korean Studies (Lyan). Although direct experience with Korea and Koreans is limited by geographical distance, fans (re)create "Korean-ness" at home.

Since broadcasting the Korean TV drama Nae Ireumeun Kim Sam-soon/My Lovely Sam-Soon (2005) in Israel in 2006, the number of Israelis interested in Korean culture has grown from tens to thousands. The Israeli mass media, for its part, has occasionally reported on the Hallyu phenomenon, adding to the exotic image of Korean culture along with the labeling of fans as "Others" (Lyan and Levkowitz, "Consuming the Other"). It may be that both the "exotic" and "foreign" perspectives of the Korean TV drama among fans are reminiscent of a tourist experiencing foreign landscapes (Chua, "Identification;" Chua, "Desire"). Although Israel is culturally heterogeneous and there is a demand for exotic cultures, combined with a fascination for "otherness," until recently, Korean culture was little known in Israel, at least in comparison to Chinese and Japanese cultures whose presence were felt predominantly in Israel in the areas of design, art, food, and leisure (GoldshteinGideoni; Daliot-Bul; Lemish and Bloch).

From our observations in Israel during the last decade, Hallyu fans have been highly instrumental in spreading interest in Korean culture and, more broadly, in Korea itself. As marketing agents, fans are particularly effective: They work for no or little payment, they themselves consume Hallyu products in large quantities, they tend to gather in groups/communities to enforce a combined commitment to their role as agents, and with an almost religious zeal they tirelessly try to convince other people to familiarize themselves with Hallyu. To bring Korea closer to Israel is one of the central objectives of Hallyu activists who, similar to other fans around the world, regularly translate Korean TV dramas and K-pop music into local languages, organize events, and educate others about Korean history, society, and culture. This sense of mission emerges out of the Israeli context since little is known about Korea and many fans regard themselves as cultural ambassadors (Lyan and 
Levkowitz, "Hallyu Land"). In what follows, we present the stories of three female entrepreneurs who each took a different route in bringing "Korea" to Israel.

\section{HALLYU ECONOMY}

Noga, ${ }^{1}$ a middle-aged woman, started to watch Korean TV dramas by chance in 2007 and loved them immediately. Since then, she has become one of the most enthusiastic Hallyu activists, translating TV dramas into Hebrew, learning Korean, and even making and selling Korean food as a business. After seeing a Facebook ad looking for a chef to cook for a team of Korean engineers in a peripheral Israeli city, she gave up everything to take a two-year job based in a rural part of Israel, learning from her Korean boss the secrets of Korean cuisine. In 2016 Noga has opened a small food catering business, initiated Korean food workshops, and participated in food fairs. In addition, she manages her own Facebook page with 1,676 followers and a smaller Facebook group with 1,554 members (as of October 2018) who share and discuss in Hebrew the recipes of Korean dishes.

When interviewed in August 2018, Noga shared her plans for moving her business forward by collaborating with Korean scholars in Israel. She is planning to organize a series of workshops to educate a wider public about Korea and to try Korean cuisine. "I myself want to learn," she explained. "To understand Korean food better I need to know more about Korea." As for the opening Korean restaurant, she feels uncertain. Her home-based enterprise, advertised for the most part through the social media, seems to her as the safest and the best way to promote her business. At her apartment, guests, for the most part fans themselves, can learn in small groups about cooking, discuss with the host food recipes, and share freely their love for Korean popular culture. In some cases, she puts on K-pop music or TV drama and shows her guests pictures and souvenirs she brought from Korea. In other words, together with food, Noga sells a cultural experience closely related to Hallyu fandom.

In the Israeli context, food entrepreneurship is a complicated process since some of the fans eat only kosher food due to religious beliefs. While not all Israelis keep the kosher laws, a significant part of Hallyu fans define themselves as religious or traditional, keeping religious laws, whilst being attracted by the modest and asexual content of Korean TV drama (Lyan and Levkovitz, "Hallyu Land"). Due to this fact, for these fans, traveling to Korea is rather difficult. While Noga keeps to the kosher regulations and adapts Korean tastes for local audiences by making new combinations in the creative process of food translation, another fan decided to go one step further by organizing women-only kosher travel tours to Korea, thus 
accommodating religious female fans. Through kosher Korean food, therefore, Hallyu entrepreneurs not only bring Korea closer to Israel in a symbolic way by having them consume Korea through eating, but they also physically bring Hallyu fans to Korea.

Noga's journey from loving Korean TV dramas to becoming a businesswoman with a Korean cuisine is just one example of the entrepreneurship of fans who have taken their fandom a step further and utilized their passion, driven by both economic and cultural motives. Among other Hallyu entrepreneurs we met, there is one who sells Korean cosmetics, another who opened an online shop for K-pop merchandise such as posters of K-pop figures, and others who organize tours to Korea, teach Korean, and even opened their own language school. The initial clients of these entrepreneurs are, for the most part, Hallyu fans themselves, but gradually a second wave of consumers, including those who are not necessarily Hallyu fans, is growing. Noga belongs to the first generation of Hallyu fans in Israel, serving as a role model for other fan entrepreneurs wishing to emulate her success.

\section{HALLYU ACADEMY}

With the rising popularity of Hallyu, the number of students taking Korean Studies has dramatically increased across world. Hallyu has become a gateway to a broader interest in the Korean language, history, and society, and in many countries, it is the main reason for students entering Korean classes. In Israel, Korean language courses started at The Hebrew University of Jerusalem in the 1990s, but due to the increase in the number of students wanting to study about Korea, a comprehensive major program was launched successfully in 2013. Since then, other universities in Israel have begun offering Korea-related courses and a few private language schools now offer Korean language classes. The Korean Cultural Center in Jerusalem, for example, founded in 2007 and managed and supported by the Korean Christian community in Israel, offers regular Korean language classes.

Based on the sixteen in-depth interviews with Korean Studies students at The Hebrew University of Jerusalem conducted in 2017, fourteen defined themselves as Hallyu fans and explicitly said that fandom is what brought them to dedicate their university years to study about Korea. Many of them mentioned that they have been stigmatized by their family and friends for their choice of what is perceived to be an impractical and "strange" degree, since popular culture is associated with youth, fun, and leisure, whereas universities symbolize the transitional step to adulthood and a professional life. For this reason, some referred to their choice of Korean studies as "a brave move," but mentioned that they are nevertheless happy with it. 
Being torn between Hallyu fandom and academic studies, "Hallyu students" try to mediate these contradictory concepts and legitimize their study choice. Some combine Korean studies with a "practical degree" to create a balance between their fandom and their future profession. Others prioritize learning Korean and having the opportunity to go to Korea on an exchange program. Finally, some understand their studies as being part of a wider mission in promoting Korean culture in Israel beyond popular culture. For instance, since the 2010s, Hallyu students have taken a major role in promoting Korean culture by organizing "Korea Day" events at the university.

The story of Sarah, a Hallyu fan since her teens, provides an illustrative example. Sarah, who comes from a religiously conservative family, decided to enroll in the Korean Studies program at The Hebrew University of Jerusalem in 2014. During her studies, she participated in and later volunteered to help organize Korea-related events on campus. To improve her Korean, she met with students from the Korean Christian community living in Jerusalem and befriended people in the community despite their cultural, language, and religious differences. Subsequently, she took a part in an intensive language course exchange program with a Korean university, but rather than only studying, she also participated in a Korean talent show, singing in Korean, and for some time she became a local celebrity. After returning to Israel and finishing her studies, she started offering her services as both a Korean-Hebrew interpreter and translator and a teacher of Korean language.

Like Noga, Sarah has become a role model for many Israeli students learning about Korea. Her knowledge and social achievements during her studies in both Israel and Korea and her ability to bridge language and cultural gaps, bringing both sides closer to each other, are highly appreciated by her fellow students. Her personal connections to different communities - the fan community in Israel and the community of Koreans living in Jerusalem-have placed her in a strategic position to combine her fandom with her career. In this context, Sarah provides a good example of a fan who is skilled and knowledgeable about Korea, filling the position of expert and educator about Korea that was lacking before the late 2010s. Previously, teaching about Korea was mostly done by Korean wives married to Israeli men, Korean Christian students studying in Israel, or a few Israeli students, non-Hallyu fans, who earned their MA in Korea under a governmental scholarship. Nowadays, however, Hallyu students are becoming the next generation of educators and mediators between Korea and Israel who choose this path for cultural rather than solely economic reasons. 


\title{
HALLYU ACTIVISM
}

\author{
Please pass on a message to all Koreans in South Korea about how many people love \\ them and their culture here in Israel; let them know how much love we have for them. \\ And let Israelis know that there are Koreans and they are amazing (an Israeli Hallyu fan \\ as cited in Lyan and Levkowitz, "Hallyu Land").
}

To bring Korea closer to Israel has become one of the main objectives of Hallyu activists who, similar to other fans around the world, translate Korean TV dramas and K-pop music into local languages, organize events, and educate others about Korean history and culture. This sense of mission emerges out of the Israeli context since, until recently, the general public knew very little about Korea and many fans feel they need to take the uninvited position of cultural ambassador. For this purpose, groups of Hallyu fans have even established NGOs to promote Korean culture in Israel. While they are mostly engaged in cultural events, like co-organizing the annual K-pop world festival, they invigorate interest in Korea and act to educate both Hallyu fans and the wider Israeli audience. Lea and Chen provide an illustrative example of this.

Lea, a pensioner and a first-generation Hallyu fan in Israel, has worked for several years in bringing K-pop bands to Israel. For this purpose, she gathered a team of dedicated Hallyu fans and Israel-loving Christian Koreans who met with Korean government officials, contacted media industry personnel in both countries, and enthusiastically campaigned for this mission, traveling back and forth several times, until her goal was achieved in 2017. But, for the most part, Lea acts solo, proudly seeing herself as one of the first to bring Korean culture to Israel.

Chen, another fan entrepreneur in her early twenties, who manages an NGO aimed at promoting Korean culture in Israel, decided to fully embrace the NGO project when she reached the conclusion that Facebook alone did not fulfill her vision. Besides online activities, the NGO, founded together with a group of Hallyu fans coming mostly from the Korean Studies program at The Hebrew University of Jerusalem, initiates offline events such as parties, dance competitions, Korean culture quizzes, food tastings, etc. In addition, the NGO aims to reach beyond the Hallyu community by organizing flash mobs or Korean food tastings in public places. Any earnings they make go back into the organization to finance more events and, in some cases, the members even pay from their own pocket, making their work more than voluntary. They also support a few Israeli K-pop dance groups, dance themselves, and publicize their dancing widely on the NGO's Facebook page $(2,514$ followers as of October 2018) and YouTube channel. 
According to Chen, her organization is modelled on AMAI, ${ }^{2}$ a Japanese anime fan organization established in 2007, which is much more institutionalized and bigger in scale than Chen's (thousands of fans take part in "Harukon," AMAI's annual April event). To promote Japanese culture, it works closely with the Japanese Embassy in Israel and the Israel-Japan Friendship Association. In a similar way, Chen's NGO, called "Korea and I,"3 collaborates with the Korean Embassy in Israel. For the last four years it has co-organized the annual K-pop World Festival, which is a multi-step international song and dance competition held around the world. Chen's NGO decided on the Israeli location, drafted the guidelines in Hebrew, and translated them into Arabic and English, while the embassy provided funding and attracted sponsorship from Samsung and LG. Both the NGO and the embassy also worked on attracting Israeli and Korean media attention. Since 2017, with the support of the Korean Embassy, K-pop bands coming from Korea have also participated in the festival. For both Lea and Chen, mediating this kind of collaboration between fan-activists, governments, and the industry illustrates the essence of their entrepreneurship.

\section{CONCLUDING REMARKS}

Fan is generally-and very likely correctly-believed to be a shortened form of fanatic. The origin of fanatic (which can be traced back to the Latin word fanum, meaning "sanctuary, temple") is less often commented on. In English, fan made an early appearance in the late 17 th century only to disappear for two centuries, resurfacing in the late 19th century. In this later period of use, it often referred to the devoted observers of, or participants in, a sport. ("Fan")

During the 200os, many observers, including academic scholars, were skeptical of the continuity of Hallyu's global acceptance, viewing it more as a passing fashion. Today, we can say with confidence that Hallyu has not disappeared but continues to be practiced and promoted by dedicated fans worldwide. Thinking about the religious origins of the word "fan" enables us to understand why fans continue to practice their fandom despite sometimes negative reactions from outsiders and promote it in their everyday lives through entrepreneurial work, study, or voluntary activities. In other words, it is the "worshippers" of Hallyu - the fans-who give it much of its energy to continue and spread even in places where people know very little about Korea.

In research on the transnational spread of cultural products, the emphasis is on organizations as the main agents, which connect different markets and communities across the globe. The literature on agency in the field of media 
studies typically focuses on companies, agencies, and technologies which convert ideas and innovations into a set of marketable products and bring them to the attention of consumers (for example, Shim and Noh; Oh and Park; E.-Y. Jung; Jin, Smartland Korea). However, the literature on Hallyu fandom usually describes fans as receptive individuals who manage to mediate cultural differences with Korea and make Hallyu part of their identity. Although some studies view fans as cultural agents, they generally overlook their role as entrepreneurs who construct necessary links between fan enthusiasm and the long-term institutional expansion and growth of Hallyu.

Focusing on Hallyu in Israel, our study described the way that Hallyu continues to circulate, not only by being transferred to other countries and accepted or appropriated by consumers, but also how it encourages fans to venture into new arenas in the realm of business and society. As we described earlier, Hallyu fandom has unleashed a great amount of entrepreneurial energy, and the resulting entrepreneurial activities support Hallyu in return by expanding its reach to new communities. In this context, the unintended consequences of Hallyu-developing new platforms for Hallyu distribution-are no less important than the intended and direct consequences of Hallyu production and marketing (reaching out to more consumers). In other words, the role of fan entrepreneurship in the global spread of Hallyu should not be underestimated. Even in an era of globalization, where ideas, images, and cultures are supposed to circulate freely and easily, fan entrepreneurs play a pivotal role as mediators and expanders, effectively bridging cultures and markets.

Although we have looked at the different, sometimes overlapping, contexts of economic activity, academic studies, and activism, the process of translation, both linguistic and cultural, appears to be vital for Hallyu entrepreneurship to move back and forth between two cultures in order to bring them closer to each other. Future research can follow more closely and systematically the mechanisms of individual entrepreneurial work among Hallyu fans in different parts of the world and examine the process of translation and coproduction of "Korea" abroad with or without collaboration with macro-agents of Hallyu. 


\section{Acknowledgments}

The research for this article was supported by the Laboratory Program for Korean Studies, the Ministry of Education of the Republic of Korea, and the Korean Studies Promotion Service of the Academy of Korean Studies (AKS-2015LAB-2250003). An earlier version of this paper was presented in the workshop "Transnational Diffusion: Regional Fandom Formation and the Globalization of Hallyu," Korea University, August 20, 2018. We wish to thank the organizers and participants for their helpful comments. 


\section{Notes}

1. All names have been changed for the purpose of anonymity.

2. See Anime and Manga Association of Israel (AMAI) website: www.amai.org.il.

3. See Korean and I website: http://kandi.org.il. 


\section{Works Cited}

Aggestam, Maria. "Art-Entrepreneurship in the Scandinavian Music Industry."

Entrepreneurship in the Creative Industries: An International Perspective, edited by Colette Henry, Edward Elgar Publishing, 2007, pp. 30-53.

Anime and Manga Association of Israel (AMAI). www.amai.org.il. Accessed 1o Oct. 2018.

Caves, Richard E. Creative Industries: Contacts between Arts and Commerce. Harvard UP, 2000.

Cho, Younghan. "Desperately Seeking East Asia amidst the Popularity of South Korean Pop Culture in Asia." Cultural Studies, vol. 25, no. 3, 2011, pp. 383-404.

Chua, Beng Huat. "Delusional Desire: Soft Power and Television Drama." Popular Culture and the State in East and Southeast Asia, edited by Nissim Kadosh Otmazgin and Eyal Ben-Ari, Routledge, 2012, pp. 35-81.

-.. "Structure of Identification and Distancing in Watching East Asian Television Drama." East Asian Pop Culture: Analysing the Korean Wave, edited by Beng Huat Chua and Koichi Iwabuchi, Hong Kong UP, 2008, pp. 73-89.

Chua, Beng Huat, and Koichi Iwabuchi. East Asian Pop Culture: Analysing the Korean Wave. Hong Kong UP, 2008.

Daliot-Bul, Michal. "Eroticism, Grotesqueness and Non-sense: Twenty-First-Century Cultural Imagery of Japan in the Israeli Media and Popular Culture." Journal of Intercultural Studies, vol. 28, no. 2, 2007, pp. 173-191.

Elfving-Hwang, Joanna. "South Korean Cultural Diplomacy and Brokering 'K-Culture' outside Asia." Korean Histories, vol. 4, no. 1, 2013, pp. 14-26.

"Fan." Merriam-Webster, www.merriam-webster.com/dictionary/fan. Accessed 12 June 2018.

Goldshtein-Gideoni, Ofra. “'Japan is Here?'-Japan as Cultural Alternative in Israel of 20oos." Israeli Sociology, vol. 1, 2003, pp. 193-218.

Han, Benjamin. "K-pop in Latin America: Transcultural Fandom and Digital Mediation." International Journal of Communication, vol. 11, 2017, pp. 2250-2269.

Hemati, Shima. "Against All Odds: South Korea's Nation Branding Campaign in Iran." Paper presented at "The 'Miracle' Narrative of the Korean Cultural Industries: Perspectives from the Middle East," The Hebrew University of Jerusalem, 7-9 May 2013.

Hirsch, Paul M. "Processing Fads and Fashions: An Organization-Set Analysis of Cultural Industry Systems." American Journal of Sociology, vol. 77, no. 4, 1972, pp. 639-659.

Jenkins, Henry. Textual Poachers: Television Fans and Participatory Culture. Routledge, 2012.

Jin, Dal Young. New Korean Wave: Transnational Cultural Power in an Age of Social Media. $\mathrm{U}$ of Illinoi P, 2016.

--. Smartland Korea: Mobile Communication, Culture, and Society. U of Michigan P, 2017.

Jin, Dal Yong, and Tae-Jin Yoon. "The Korean Wave: Retrospect and Prospect." International Journal of Communication, vol. 11, 2017, pp. 2241-2249.

Jung, Eun-Young. "Transnational Korea: A Critical Assessment of the Korean Wave in Asia and the United States." Southeast Review of Asian Studies, vol. 31, 2009, pp. 69-80. 
Jung, Sun. "Fan Activism, Cybervigilantism and Othering in K-pop Fandom."

Transformative Works \& Cultures, vol. 10, 2012. Transformative Works and Cultures, https://doi.org/10.3983/twc.2012.0300. Accessed 17 Sept. 2018.

Jung, Sun, and Doobo Shim. "Social Distribution: K-pop Fan Practices in Indonesia and the 'Gangnam Style' Phenomenon." International Journal of Cultural Studies, vol. 17, no. 5, 2014, pp. 485-501.

Kim, Suwan. "The New Korean Wave in the Middle East and its Role in the Strategic Approach to Medical Tourism in Korea." Kritika Kultura, vol. 29, 2017, pp. 258-271.

King Sejong Institute. www.sejonghakdang.org/sjcu/home/main.do. Accessed 5 Oct. 2018.

Korean and I. http://kandi.org.il. Accessed 7 Oct. 2018.

Kuratko, Donald F., and David B. Audretsch. "Strategic Entrepreneurship: Exploring Different Perspectives of an Emerging Concept." Entrepreneurship: Theory and Practice, vol. 1, no. 33, 2009, pp. 1-17.

Lee, Sangjoon, and Marcus Nornes, editors. Hallyu 2.o: The Korean Wave in the Age of Social Media. U of Michigan P, 2015.

Lee, Seung-Ahn. "Of the Fans, For the Fans: The JYJ Republic." Hallyu 2.o: The Korean Wave in the Age of Social Media, edited by Sangjoon Lee and Marcus Nornes, U of Michigan P, 2015, pp. 108-129.

Lemish, Dafna, and Linda-Renee Bloch. "Pokémon in Israel." Pikachu's Global Adventure: The Rise and Fall of Pokémon, edited by Joseph Tobin, Duke UP, 2004, pp. 165-186.

Lie, John. "What is K in K-pop? South Korean Popular Music, the Cultural Industry, and National Identity." Korea Observer, vol. 43, no. 3, 2012, pp. 339-363.

Lyan, Irina. "Welcome to Korea Day: On Performing Nationalism by the Korean and Hallyu Students in Israel." Paper presented at the "Consumption and Culture" Workshop, The Open University, 21 Oct. 2017.

Lyan, Irina, and Alon Levkowitz. "Consuming the Other: Israeli Hallyu Case Study." Hallyu 2.o: The Korean Wave in the Age of Social Media, edited by Sangjoon Lee and Markus Nornes, U of Michigan P, 2015, pp. 212-228.

Lyan, Irina, and Alon Levkowitz. "From Holy Land to 'Hallyu Land': The Symbolic Journey Following the Korean Wave in Israel." Journal of Fandom Studies, vol. 3, no. 1, 2015, pp. 7-21.

Lyan, Irina, Sulafa Zidani, and Limor Shifman. "When Gangnam Hits the Middle East: Re-makes as Identity Practice." Asian Communication Research, vol. 12, no. 2, 2015, pp. $10-31$.

McGrath, Rita Gunther, and Ian C. MacMillan. The Entrepreneurial Mindset: Strategies for Continuously Creating Opportunity in an Age of Uncertainty. Harvard Business School Press, 200o.

Min, Wonjung, Dal Yong Jin, and Benjamin Hall. “Transcultural Fandom of the Korean Wave in Latin America: Through the Lens of Cultural Intimacy and Affinity Space." Media, Culture E Society, 2018. Sage Journals, https://doi. org/10.1177/0163443718799403. Accessed 7 Sept. 2018.

Morris, Michael H., Donald F. Kuratko, and Jeffrey G. Covin. Corporate Entrepreneurship and Innovation. Thomson/South Western Publishers, 2008. 
"Muslim-friendly Travel." Korea Tourism Organization, http://english.visitkorea.or.kr/enu/ ATR/muslim_intro.jsp. Accessed 5 Oct. 2018.

Noh, Sueen. "Unveiling the Korean Wave in the Middle East." Hallyu: Influence of Korean Culture in Asia and Beyond, edited by Do Kyun Kim and Min-Sun Kim, Seoul National UP, 2010, pp. 331-367.

Oh, Ingyu. "Islam and Local Culture: The Peril of State Violence and Hallyu Fandom in Indonesia (With Reference to Palestine)." Kritika Kultura, vol. 29, 2017, pp. 232-257.

--. "Torn between Two Lovers: Retrospective Learning and Melancholia among Japanese Women." Korea Observer, vol. 42, no. 2, 2011, pp. 223-254.

Oh, Ingyu, and Gil-Sung Park. "From $\mathrm{B}_{2} \mathrm{C}$ to $\mathrm{B}_{2} \mathrm{~B}$ : Selling Korean Pop Music in the Age of New Social Media." Korea Observer, vol. 43, no. 3, 2012, pp. 365-397.

Otmazgin, Nissim Kadosh. "Anime in the US: The Entrepreneurial Dimensions of Globalized Culture." Pacific Affairs, vol. 87, no. 1, 2014, pp. 53-69.

-.. "Commodifying Asian-ness: Entrepreneurship and the Making of East Asian Popular Culture." Media, Culture \& Society, vol. 33, no. 2, 2011, pp. 259-274.

Otmazgin, Nissim Kadosh, and Irina Lyan. "Hallyu across the Desert: K-pop Fandom in Israel and Palestine." Cross-Currents: East Asian History and Culture Review, vol. 3, no. 1, 2014, pp. 32-55.

Peterson, Richard A., and David G. Berger. "Entrepreneurship in Organizations: Evidence from the Popular Music Industry." Administrative Science Quarterly, vol. 16, 1971, pp. 97-106.

Schulze, Marion. "Korea vs. K-Dramaland: The Culturalization of K-dramas by International Fans." Acta Koreana, vol. 16, no. 2, 2013, pp. 367-397.

Scott, Michael. "Cultural Entrepreneurs, Cultural Entrepreneurship: Music Producers Mobilising and Converting Bourdieu's Alternative Capitals." Poetics, vol. 40, no. 3, 2012, pp. 237-255.

Sharma, Pramodita, and Sankaran James J. Chrisman. "Toward a Reconciliation of the Definitional Issues in the Field of Corporate Entrepreneurship." Entrepreneurship: Concepts, Theory and Perspective, edited by Álvaro Cuervo, Domingo. Ribeiro, and Salvador Roig, Springer Berlin Heidelberg, 2007, pp. 83-103.

Shim, Doo-Bo, and Kwang-Woo Noh. "YouTube and Girls' Generation Fandom." The Journal of the Korea Contents Association, vol. 12, no.1, 2012, pp. 125-137.

Story, John. Cultural Consumption and Everyday Life. Arnold, 1999.

Swedberg, Richard. "The Cultural Entrepreneur and the Creative Industries: Beginning in Vienna." Journal of Cultural Economics, vol. 30, no. 4, 2006, pp. 243-261.

Venkataraman, Sankaran. "The Distinctive Domain of Entrepreneurship Research." Advances in Entrepreneurship, Firm Emergence and Growth, vol. 3, no. 1, 1997, pp. 119-138.

Welter, Friederike. "Contextualizing Entrepreneurship_Conceptual Challenges and Ways Forward." Entrepreneurship Theory and Practice, vol. 35, no. 1, 2011, pp. 165-184.

Zahra, Shaker A. "Contextualizing Theory Building in Entrepreneurship Research." Journal of Business Venturing, vol. 22, no. 3, 2007, pp. 443-452. 